\title{
African Indigenous Vegetables and their Production Practices: Evidence from the HORTINLEA Survey in Kenya
}

Kebede SW* and Bokelmann W

Division of Horticultural Economics, Humboldt - Universität zu Berlin, Berlin, Germany

\begin{abstract}
Although indigenous vegetables (AIVs) have always been a staple food crop, the promotion of their production, marketing and consumption is a recent phenomenon. There is already consensus that AIVs contribute to food security by providing a variety of nutrients, while easing food insecurity tensions during periods of food shortages. This study found that the AIV producers sampled in Kenya followed sustainable production practices by predominantly using organic fertilizer and thus maximizing natural biological processes and promoting local biodiversity, both of which help improve soil fertility and environmental sustainability. In addition, the use of local seeds minimized farm expenses and the cost of non-renewable inputs. This study focused on fertilizer use, with the aim of identifying the main socioeconomic factors determining the use of different types of fertilizer among AIV farmers. The ordered probit model found that larger (in terms of household size) and better-off households were more likely to use organic fertilizer. In addition, receipt of remittances, distance to market, access to information about fertilizer application and living in a rural area increased the likelihood of organic fertilizer being used. Given the contribution of AIVs to food security and their production processes complying with sustainable production, it is recommended that their production and marketing should be promoted and scaled up.
\end{abstract}

Keywords: African indigenous vegetables; Production practices; Fertilizer; Seed; Kenya

\section{Introduction}

Even though African indigenous vegetables (AIVs) ${ }^{1}$ have always been a staple food crop, their promotion in terms of production and marketing is a recent phenomenon. This is because they used to be primarily considered as food for rural and poor households only. However, the market for these products has recently been developed and awareness rose with regard to their consumption. For instance, supermarkets in Nairobi have been selling AIVs since 2000, albeit in small quantities [1]. These recent developments indicate that AIVs are now being included in the diets of both urban and rural populations and that demand for them is increasing [2]. This calls for a review of their contribution to household food security and an assessment of production practices.

\section{Changing food systems}

In many developing countries, agricultural and food systems are undergoing major transformations into high-value, modern supply chains [3]. Markets are increasingly driving agricultural development. For most of the $20^{\text {th }}$ century, major progress in agricultural development was linked to significant improvements in the productivity and marketing of staple food crops. However this situation is changing. With falling staple food prices and rising urban incomes, there has been a shift towards strategies that enhance agricultural diversification and increase the added value of agricultural production [4]. Driven by rising incomes, demographic shifts and globalisation, there has been an extensive change to diets in the developing world. Consumers are shifting to more diverse diets that are higher in fresh produce and animal products and contain more processed foods [5]. Therefore, agricultural sectors around the world are increasingly diversifying into vegetables and fruits, spices, aquaculture products and non-food products. Horticulture

${ }^{1}$ The definition of indigenous vegetables for the present study has been taken from Schippers (2000), who describes indigenous vegetables as those whose primary or secondary centre of origin is in the respective location: here, Kenya. is often the fastest growing sector within the agricultural sector, contributing to poverty alleviation and nutritional security, offering income opportunities and generating huge employment opportunities along the value chain [4].

Increasingly, as a result of all these factors, the food systems in many countries are changing. They range from village markets selling locally produced and consumed products to global markets selling packaged, off-season vegetables for instance. Traditional and modern markets exist in parallel, with varying degrees of integration at the local, urban, national, regional and global level. Market differentiation offers new opportunities for smallholder farmers, along with new risks and barriers [6]. Traditional food systems are characterized by the dominance of unorganized supply chains and a limited market infrastructure. Structured food systems still feature the traditional actors, but with more rules and regulations applied to the marketplace and a greater market infrastructure. Structured food chains are beginning to capture a growing share of the market. Export value chains are characterized by strong perceptions of safety, a high degree of coordination, a large and consolidated processing sector and organized retailers. Structured (modern) food chains in developing countries are advancing rapidly due to global exposure, competition and investment, while traditional chains - still very important in Kenya - risk stagnation, partly due to underinvestment [6].

${ }^{*}$ Corresponding author: Kebede SW, Division of Horticultural Economics, Humboldt - Universität zu Berlin, Berlin, Germany, Tel: +49-30-2093-46345 E-mail: kebedesw@agrar.hu-berlin.de

Received October 20, 2017; Accepted October 25, 2017; Published November 01, 2017

Citation: Kebede SW, Bokelmann W (2017) African Indigenous Vegetables and their Production Practices: Evidence from the HORTINLEA Survey in Kenya. Agrotechnology 6: 170. doi: 10.4172/2168-9881.1000170

Copyright: (c) 2017 Kebede SW, et al. This is an open-access article distributed under the terms of the Creative Commons Attribution License, which permits unrestricted use, distribution, and reproduction in any medium, provided the original author and source are credited. 
In summary, horticultural produce and processed products are becoming increasingly popular in developing countries, both for domestic and international markets. Production and consumption are rising steadily. While experience shows that horticulture offers good opportunities for poverty reduction by increasing income and generating employment, care must be taken to ensure that smallholder and poor farmers are not excluded [7]. The challenge is to ensure that smallholder farmers benefit from the changes in the food system and are not excluded from 'modern' chains.

\section{Agricultural production practices}

There are various definitions and indicators in the literature regarding the procedures and activities of agricultural production practices [8-10]. However, most agree on the core idea that agricultural production processes should meet current production goals without compromising the future in terms of resource degradation and depletion, and therefore on the importance of the notion of sustainability in agricultural production practices [11]. It is suggested that indicators such as seed source, type of fertilizer, irrigation, pest/ disease control and weed control among others should be considered in order to assess production practices in agriculture [8].

It is generally believed that AIV production conforms to ecologically sound land management systems. This is because it uses organic farming practices, requires low soil moisture, and AIVs grow well even during abiotic and biotic stresses $[9,10]$. However, there has been no extensive study of the effect of AIV production on the environment in general or examination of their production practices in particular. This is because AIVs are usually produced in backyards/ home gardens or are inter-cropped with other crops, which means that research is not focused on AIV production alone or on the agricultural practices around AIVs using household survey data. In order to fill this research gap, this paper comprises the following:

a) A review of the food and nutrition contribution of AIVs

b) An exploration of AIV production processes

c) Identification of the major determinants of AIV production practices at household level, with the focus on fertilizer.

\section{Data Source and Methodology}

\section{Data source}

This study used data from the HORTINLEA survey ${ }^{2}$ undertaken in rural and peri-urban areas of Kenya between September and October 2014. The survey focused on five indigenous vegetables: amaranth (Amaranthus species), cowpeas (Vignaunguiculata), African nightshade (Solanum species), spider plant (Cleome gynandra), and Ethiopian kale (Brassica carinata). The specific survey sites were selected after consultation with experts about where most indigenous vegetables are produced, both for home consumption and sale in markets in Kenya. The rural sites were in two counties in Western Kenya: Kisii and Kakamega. The peri-urban sites were in three counties: Kiambu, Nakuru and Kajiado. A total of 1232 AIV producers in these rural and peri-urban sites were interviewed (see Table A1 and Figure A3 in the Annex).

${ }^{2}$ The HORTINLEA household survey is conducted by Humboldt University of Berlin in collaboration with Egerton University and Leibniz University of Hannover. The data collection is funded as part of the initiative for global food security (GlobE) of the German Federal Ministry of Education and Research and the German Federal Ministry for Economic Cooperation and Development.

\begin{tabular}{|c|c|c|}
\hline Area description & County & $\begin{array}{c}\text { Number of households } \\
\text { interviewed }\end{array}$ \\
\hline Rural & Kisii & 401 \\
\hline & Kakamega & 405 \\
\hline Peri-urban & Nakuru & 223 \\
\hline & Kiambu & 183 \\
\hline & Kajiado & 20 \\
\hline & & 1232 \\
\hline
\end{tabular}

Table A1: HORTINLEA survey sites and number of respondents.

The households in the survey were selected using the multistage sampling approach. First, a purposive sampling technique was used to select the five counties within the rural and peri-urban sites. It was purposive in that the respondents within these counties are involved in the production, marketing or consumption of at least one of the aforementioned indigenous vegetables. The selection of the sub-counties and divisions was based on information from the respective district agricultural offices. From each division, locations/ ward was randomly selected, and in turn households within locations were randomly selected. In all the locations, the survey was carried out through direct interviews with farmers engaged in indigenous vegetable farming and marketing.

It is important to note that the HORTINLEA household survey is not representative at a national level. However, the data do provide a comprehensive overview of indigenous vegetable producers in rural and peri-urban areas, given that relatively large samples were taken within each county. Therefore, the results of the analysis performed on the survey data can be generalized to indigenous vegetable producers in rural and peri-urban areas.

\section{Methodology}

The socioeconomic factors determining AIV production practices in rural and peri-urban areas were analyzed, with the focus on the application of fertilizer. The farmers' use of fertilizer was divided into four categories: no fertilizer, inorganic fertilizer, both organic and inorganic fertilizers, and only organic fertilizer. This type of classification called for the use of the ordered probit model, where the dependent variable $Y_{i}$ is logically ordered ( 0 to 3 in the present case: 0 : farmer does not use fertilizer; 1 : farmer uses inorganic fertilizer, 2: farmer uses both organic and inorganic fertilizers, and 3: farmer uses organic fertilizer) [12]. Since the objective here was to identify factors that influence the use of organic fertilizer as compared to the other types of fertilizer use (namely both organic and inorganic, or only inorganic), it was decided to design the logical ordering in such a way that the highest value was assigned to only organic fertilizer use.

Therefore, in the ordered probit model, the modalities of the dependent variable $Y_{i}$ were:

$\left\{\begin{array}{l}Y_{i}=0 \text { (if hh does not apply fertiliser) if } Y_{i}^{*}<C_{1} \\ Y_{i}=1 \text { (if hh uses not inorganic fertiliser) if } \mathrm{C}_{1} \leq Y_{i}^{*}<C_{2} \\ Y_{i}=2 \text { (if hh uses not inorganic and organic fertiliser) if } \mathrm{C}_{2} \leq Y_{i}^{*}<C_{3} \\ Y_{i}=3 \text { (if hh uses organic fertiliser only) if } \mathrm{C}_{3} \leq Y_{i}^{*}\end{array}\right.$

The ordered probit model is described as:

$Y_{i}^{*}=X_{i} \beta+u_{i}$

where $X_{i}$ is a vector of explanatory variables

$\beta$ is a vector of the associated coefficients

$u_{i}$ is a random component. 


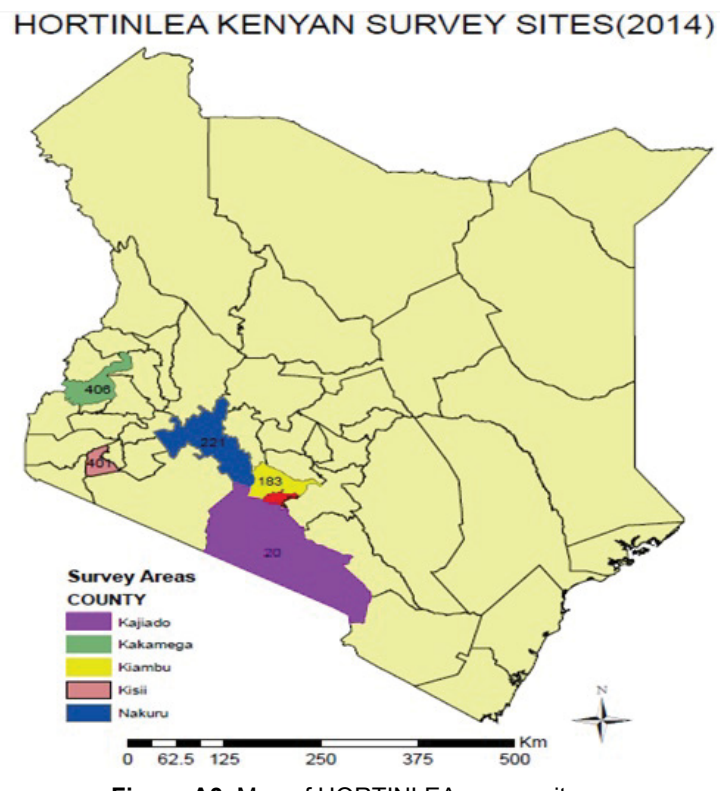

Figure A3: Map of HORTINLEA survey sites.

In the model, an underlying score was estimated as a linear function of the set of independent variables and a set of cut points $C_{i}$. The probability of observing outcome $i$ corresponds to the probability that the estimated linear function, plus random error, is within the range of the cut points estimated for the outcome:

$$
\operatorname{Pr}\left(\text { Outcome }_{j}=i\right)=\operatorname{Pr}\left(C_{i-j}<X_{i} \beta+u_{i} \leq C_{i}\right)
$$

The marginal probabilities could therefore be calculated from the probit model as:

$$
\frac{d p r o b\left[Y_{k}\right]}{d X_{k}}=\left[\phi\left(C_{i-j}+\beta^{\prime} X_{i}\right)-\phi\left(C_{i-j}+\beta^{\prime} X_{i}\right)\right] \beta
$$

Where $\varnothing($.$) is the normal density function and C_{i}$ is the threshold parameter.

The explanatory variables included in the model were categorised into household characteristics (including the age of the head of the household, sex of the head of the household, household size, education level of the head of the household and marital status), household wealth status (household income, asset level and savings), household opportunity for diversified income source (non-farm employment and remittances received), distance to market, access to information on fertilizer application, and location (whether a rural or peri-urban household). A summary of the independent variables used is given in Table A2 in the Annex.

\section{Descriptive Results and Discussions}

\section{Contribution of indigenous vegetables to food security}

Indigenous vegetables contribute to food security in different ways. AIVs are an important source of micronutrients, including vitamins $\mathrm{A}$ and $\mathrm{C}$, iron, calcium, magnesium, proteins and anti-oxidants that are required for normal growth and health [13-15]. Thus they provide necessary energy and protein, especially for children being weaned, the sick and the elderly [9]. Indigenous vegetables are far more common in poor households and constitute the major or only source of food between harvests or when harvests fail [9]. They improve palatability

\begin{tabular}{|c|c|}
\hline & $\begin{array}{c}\text { Mean (standard deviations } \\
\text { in brackets) }\end{array}$ \\
\hline \multirow{2}{*}{ Average household size } & 5.64 \\
\hline & -2.2955 \\
\hline \multirow{2}{*}{ Average age of the head of the household } & 49.9 \\
\hline & -12.6292 \\
\hline \multirow{2}{*}{ Average income } & 17.22 \\
\hline & -37.3685 \\
\hline \multirow{2}{*}{ Average asset index } & 64.58 \\
\hline & -88.6184 \\
\hline \multirow{2}{*}{ Average distance to market } & 2.42 \\
\hline & -2.5368 \\
\hline Percentage of households & Percentage \\
\hline headed by a man & 80.32 \\
\hline where the head of the household has no education & 6.67 \\
\hline $\begin{array}{l}\text { where the head of the household had primary } \\
\text { education }\end{array}$ & 38.77 \\
\hline $\begin{array}{c}\text { where the head of the household had secondary } \\
\text { education }\end{array}$ & 40.71 \\
\hline $\begin{array}{c}\text { where the head of the household had tertiary } \\
\text { education and above }\end{array}$ & 13.85 \\
\hline where the head of the household is married & 76.87 \\
\hline $\begin{array}{l}\text { where the household has a member with a savings } \\
\text { account }\end{array}$ & 46.54 \\
\hline $\begin{array}{c}\text { where the household is engaged in off-farm } \\
\text { employment }\end{array}$ & 18.37 \\
\hline $\begin{array}{l}\text { where the household has information on fertiliser } \\
\text { application }\end{array}$ & 41.15 \\
\hline where the household receives a remittance & 33.05 \\
\hline where the household lives in a rural area & 65.58 \\
\hline
\end{tabular}
and add variety to diets, especially for the poor. Since AIV production
Table A2: Summary of independent variables used in the ordered probit model.

does not require much capital investment and only involves short labour-intensive production systems and a low level of purchased inputs, it is relatively easy for resource-poor households to plant them in their backyards or inter-crop them. Furthermore, AIVs come into production within a short time of the onset of rains and can be harvested three to four weeks after planting. They can be sun-dried and stored, serving as a source of food in the dry season or when 
the harvest fails. Moreover, AIVs are used in emergencies or during difficult periods of civil conflict and natural disasters that result in the displacement of communities. When sold in markets, AIV prices are usually cheap, making them easily accessible to the very poorest.

Women are usually considered to be the main producers of indigenous vegetables because they are easy to harvest and serve to family members. In some cases, women use these products as sources of income by selling them in nearby markets, thus enhancing their purchasing power and food production capacity and having a direct impact on household nutrition, health and food security. The survey data from Kenya showed that more than $45 \%$ of producers responded that women were responsible for the production of AIVs, while this figure was even higher for the marketing of AIVs Figure 1 at over 55\%. This supported the notion that AIVs are largely women-dominated vegetables, being primarily produced and marketed by them, and that they play a key role in ensuring the household's food security. Since women play the main role in preparing food in the household, they can feed their household from the AIVs produced, but also sell them in nearby markets to fill the food security gap in the household. Of course, further exploration is needed as to whether the money obtained from the sale of AIVs is used by the women alone or whether it is shared with the head of the household to make some other purchase that does not contribute to the household's food security.

\section{Indigenous vegetable production practices}

Among the sample of AIV producers interviewed in the rural and peri-urban areas of Kenya, the most widely produced indigenous vegetable was African nightshade, produced by about $72 \%$ of the respondents, followed by cowpeas produced by about $48 \%$ of respondents (Table 1). In the counties sampled, most of the AIV production was concentrated in the rural counties of Kisii and Kakamega, with amaranth, cowpea, spider plant and Ethiopian kale only grown in these two counties, while African nightshade was also widely grown here and in the peri-urban counties of Nakuru, Kiambu and Kajiado. Peri-urban counties produce around $10 \%$ of the country's African nightshade. This finding is consistent with the fact that African nightshade was the most widely produced AIV in the sampled households.

The average area allocated to the production of these indigenous vegetables was more or less the same, the largest being 0.21 acres for spider plant and the smallest 0.18 acres for African nightshade. These indigenous vegetables have a long history of production in the different

\begin{tabular}{|l|c|c|c|c|c|}
\hline Parameters & Amaranth & Cowpeas & $\begin{array}{c}\text { African } \\
\text { nightshade }\end{array}$ & $\begin{array}{c}\text { Spider } \\
\text { plant }\end{array}$ & $\begin{array}{c}\text { Ethiopian } \\
\text { kale }\end{array}$ \\
\hline $\begin{array}{c}\text { Percentage of } \\
\text { producers out of } \\
\text { the total }\end{array}$ & 42.2 & 48.5 & 72.7 & 44.8 & 35.5 \\
\hline \multicolumn{7}{|c|}{ By county } \\
\hline Kisii & 76.9 & 67.2 & 44.8 & 72.6 & 91.6 \\
\hline Kakamega & 23.1 & 32.8 & 45.2 & 27.4 & 8.4 \\
\hline Nakuru & - & - & 8.5 & - & - \\
\hline Kiambu & - & - & 1.3 & - & - \\
\hline Kajiado & - & - & 0.2 & - & - \\
\hline \multicolumn{7}{|c|}{ Average crop area in acres } \\
\hline Crop area in acres & 0.19 & 0.19 & 0.18 & 0.21 & 0.2 \\
\hline
\end{tabular}

Source: Authors' computation based on HORTINLEA survey data (2014)

Table 1: Indigenous vegetables and their production in rural and peri-urban Kenya (percentage of households). villages in which the survey was performed. In some villages, AIVs have been produced since the 1950s, while the highest percentage of respondents started production in 2000 . This might be due to the expansion of supermarkets and the gradual development of marketing channels to sell to peri-urban and urban consumers at relatively high prices. Furthermore, greater awareness of the benefits of AIVs to health and nutrition triggered the start of many people producing these vegetables.

The survey showed that, for the majority of households, the trend in the area planted was the same for all five focus indigenous vegetables compared to five years ago (Table 2). In contrast, the majority of respondents reported that trends in yield increased for all AIVs except for amaranth. The main reasons for the yield increase were good weather and improvements in soil fertility. The increase in average yield with the area planted remaining the same could also imply that there is a practice of agricultural intensification with these AIVs. However, it is unclear whether this agricultural intensification is being performed sustainably or not. Sustainable agricultural intensification is defined as producing more output from the same area of land while reducing the negative environmental impacts, and at the same time increasing contributions to natural capital and the flow of environmental services [16]. To analyze in greater depth the notion of intensification of AIV production, the use of fertilizer and types of seeds among the sampled AIV producers was assessed.

Most respondents reported that they did apply fertilizer while growing AIVs. This ranged from $82 \%$ of respondents using fertilizers for spider plant and Ethiopian kale to about $73 \%$ of respondents using fertilizers for amaranth (Table 3). The majority of farmers applied fertilizer just once a season, and on average about $51 \%$ of them used organic fertilizers from on-farm sources to grow these vegetables. This is in line with the argument for sustainable agricultural practices in which the use of environmentally-friendly fertilizers is promoted. Nevertheless, around $29 \%$ of the producers used inorganic fertilizers, while some producers used both organic and inorganic fertilizers for AIV production. The use of inorganic fertilizers could be a threat to sustainable agricultural production in that it increases nutrients and toxins, leading to the disruption of the ecosystem with negative biological and environmental consequences $[8,9,17,18]$. Nevertheless, the use of inorganic fertilizer might not be entirely due to AIV production alone. In Kenya, most AIVs are intercropped with other crops such as maize, which implies that the inorganic fertilizer might

\begin{tabular}{|c|c|c|c|}
\hline \multicolumn{4}{|c|}{ Trend in area planted with the product compared to five years ago } \\
\hline & Stayed the same & Increased & Decreased \\
\hline Amaranth & 58.5 & 23.2 & 18.3 \\
\hline Cowpeas & 51 & 27.8 & 21.2 \\
\hline African nightshade & 52.3 & 27.9 & 19.8 \\
\hline Spider plant & 53.2 & 26 & 20.8 \\
\hline Ethiopian kale & 49.9 & 30.7 & 19.5 \\
\hline \multicolumn{4}{|c|}{ Trend in average yield compared to five years ago } \\
\hline & Stayed the same & Increased & Decreased \\
\hline Amaranth & 42.7 & 36.5 & 20.8 \\
\hline Cowpeas & 33.9 & 42 & 24.1 \\
\hline African nightshade & 33 & 43.6 & 23.5 \\
\hline Spider plant & 32 & 44 & 24.1 \\
\hline Ethiopian kale & 28.5 & 49.7 & 21.8 \\
\hline
\end{tabular}

Table 2: Trend in area planted and yield in AIV compared to five years ago (percentage of households). 
Citation: Kebede SW, Bokelmann W (2017) African Indigenous Vegetables and their Production Practices: Evidence from the HORTINLEA Survey in Kenya. Agrotechnology 6: 170. doi: 10.4172/2168-9881.1000170

Page 5 of 7

have been applied to the intercropped product and not necessarily to AIVs exclusively.

Most of the producers bought seeds to grow AIVs, with the majority of them (between 47-67\%) purchasing standard/local seeds, as shown in Table 4. While improved seeds were rarely used, many producers used certified improved seeds. Most households bought these seeds from within the village or the sub-village.

Most of the producers did not use irrigation for AIV production, with only about $24 \%$ of respondents using irrigation for amaranth and about $20 \%$ for African nightshade (Table 5). The majority of respondents reported that there was no need for irrigation to grow these vegetables. Some also mentioned a shortage of water and shortage of money as the main reasons for not using irrigation.

\section{Determinants of Fertilizer Application: Results and Discussion}

The maximum likelihood estimates of the parameters of the ordered probit regression model for the different types of use of fertilizer are shown in Table 6. The results show that of the household's

\begin{tabular}{|c|c|c|c|c|c|}
\hline Parameters & Amaranth & Cowpeas & $\begin{array}{c}\text { African } \\
\text { nightshade }\end{array}$ & $\begin{array}{l}\text { Spider } \\
\text { plant }\end{array}$ & $\begin{array}{l}\text { Ethiopian } \\
\text { kale }\end{array}$ \\
\hline $\begin{array}{c}\text { Household uses } \\
\text { fertiliser to grow this } \\
\text { product }\end{array}$ & 73.5 & 75.4 & 81.8 & 82.6 & 82.2 \\
\hline \multicolumn{6}{|c|}{ How often did the household apply fertiliser to grow this product? } \\
\hline Once a season & 50.1 & 61.7 & 55.8 & 61.7 & 55.1 \\
\hline Twice a season & 20.5 & 19.6 & 21.1 & 20.6 & 17.8 \\
\hline $\begin{array}{l}\text { More than twice a } \\
\text { season }\end{array}$ & 27.3 & 17 & 21.1 & 14.9 & 25.7 \\
\hline Other & 0 & 1.8 & 2 & 2.8 & 1.3 \\
\hline \multicolumn{6}{|c|}{ Type of fertiliser used by the household } \\
\hline Inorganic & 28.6 & 28.9 & 29.1 & 30.6 & 27.9 \\
\hline Organic & 49.4 & 55.8 & 48.5 & 49.5 & 51.8 \\
\hline Both & 22 & 15.3 & 22.4 & 19.9 & 20.3 \\
\hline \multicolumn{6}{|c|}{ Source of fertilisers } \\
\hline On farm & 45.1 & 51.1 & 44.4 & 46.1 & 47.4 \\
\hline Outside farm & 31.3 & 31.8 & 31.9 & 32 & 29.8 \\
\hline Both & 23.6 & 17.1 & 23.7 & 21.9 & 22.9 \\
\hline
\end{tabular}

Source: Authors' computation based on HORTINLEA survey data (2014)

Table 3: Fertiliser use and source (percentage of households).

\begin{tabular}{|c|c|c|c|c|c|c|}
\hline Parameters & Amaranth & Cowpeas & $\begin{array}{c}\text { African } \\
\text { nightshade }\end{array}$ & $\begin{array}{c}\text { Spider } \\
\text { plant }\end{array}$ & $\begin{array}{c}\text { Ethiopian } \\
\text { kale }\end{array}$ \\
\hline $\begin{array}{c}\text { Household buys } \\
\text { seeds to plant this } \\
\text { product }\end{array}$ & 55 & 69.4 & 61 & 61.3 & 64.6 \\
\hline \multicolumn{5}{|c|}{ Which types of seeds were planted? } \\
\hline Standard/local seeds & 47.1 & 67.2 & 56.8 & 58.6 & 49.6 \\
\hline Improved seeds & 13.9 & 10.1 & 11.1 & 9.7 & 12.5 \\
\hline $\begin{array}{c}\text { Certified improved } \\
\text { seeds }\end{array}$ & 20.9 & 12 & 17.3 & 15.4 & 23.9 \\
\hline Recycled seeds & 17 & 10.1 & 13.8 & 16 & 12.7 \\
\hline \multicolumn{2}{|c|}{ Others } & 1.1 & 0.5 & 1 & 0.4 & 1.3 \\
\hline \multicolumn{2}{|c|}{ Where was the source of these seeds? } \\
\hline Within the sub-village & 37.5 & 39.3 & 41.3 & 42.4 & 37.4 \\
\hline Within the village & 37.3 & 33.8 & 32.6 & 33.6 & 31.8 \\
\hline \multicolumn{2}{|c|}{ Other } & 25.2 & 26.8 & 26.2 & 24 & 30.8 \\
\hline
\end{tabular}

Source: Authors' computation based on HORTINLEA survey data (2014)

Table 4: Seed use and source (percentage of households).

\begin{tabular}{|c|c|c|c|c|c|c|}
\hline Parameters & Amaranth & Cowpeas & $\begin{array}{c}\text { African } \\
\text { nightshade }\end{array}$ & $\begin{array}{c}\text { Spider } \\
\text { plant }\end{array}$ & $\begin{array}{c}\text { Ethiopian } \\
\text { kale }\end{array}$ \\
\hline $\begin{array}{c}\text { Household uses } \\
\text { irrigation to grow } \\
\text { this product }\end{array}$ & 23.48 & 10.53 & 20.69 & 15.79 & 14.43 \\
\hline \multicolumn{5}{|c|}{ Reason for not using irrigation } \\
\hline No need & 76.76 & 72.03 & 67.8 & 63.1 & 74.92 \\
\hline Shortage of water & 6.53 & 9.81 & 10.09 & 15.24 & 2.11 \\
\hline Shortage of money & 0 & 11.9 & 10.24 & 12.62 & 14.5 \\
\hline Other & 16.71 & 6.26 & 11.87 & 9.04 & 8.47 \\
\hline
\end{tabular}

Source: Authors' computation based on HORTINLEA survey data (2014)

Table 5: Irrigation use (percentage of households).

basic characteristics, household size had a significant and positive effect on the use of organic fertilizer. This was especially the case for cowpea and spider plant, and to some extent for African nightshade. This could be because availability of family labour in the household increases the likelihood of using organic fertilizers, which might require more labour resources. From the indicators of household wealth status, household income was found to have a significant and positive influence on the use of organic fertilizers for all types of vegetables except cowpea (which was not significant, yet positive). This shows that well-off households opted to use organic fertilizer to grow these vegetables. A similar finding regarding asset indices (cowpeas and spider plant) and savings (for African nightshade and Ethiopian kale) reinforced the above finding.

Availability of diversified income sources other than from agriculture was found to have a mixed effect on the use of organic fertilizers. Non-farm employment had a negative and significant effect on the use of organic fertilizer only in the case of amaranth. In contrast receipt of remittances increased the likelihood of organic fertilizer being used in the case of African nightshade, significant at a $10 \%$ level. For the rest of the vegetables, none of the diversified income sources, such as off-farm employment and receipt of remittances, had a significant effect on the use of organic fertilizer. The distance of the household to market was found to have a positive and significant effect on the use of organic fertilizer in the case of African nightshade and spider plant. This was expected since households located far away from marketplaces opted for organic fertilizers rather than inorganic fertilizers. This might increase production, but it is not a sustainable practice. African nightshade and spider plants are the most marketed vegetables in the sample households; however the result here showed that if households are far from the market their tendency to sell will be low. Hence they would rather use organic fertilizer, which is more sustainable, than inorganic fertilizer, which might result in higher production levels.

Access to information on fertilizer application was found to play a significant and positive role in the use of organic fertilizer in the production of amaranth and African nightshade. For the other vegetables, even though there was a positive relationship, the results were not statistically significant. This might be because the application of organic fertilizers such as compost might not require information from experts as such, but this is easily transferred through farm experience between family, relatives and neighbours. Finally, households from rural areas were more likely to use organic fertilizer than those from peri-urban areas. This was positively and significantly related to the use of organic fertilizer for almost all indigenous vegetables except spider plant. 
Citation: Kebede SW, Bokelmann W (2017) African Indigenous Vegetables and their Production Practices: Evidence from the HORTINLEA Survey in Kenya. Agrotechnology 6: 170. doi: 10.4172/2168-9881.1000170

Page 6 of 7

\begin{tabular}{|c|c|c|c|c|c|}
\hline & Amaranth & Cowpeas & African nightshade & Spider plant & Ethiopian Kale \\
\hline \multicolumn{6}{|c|}{ Household characteristics } \\
\hline Male household & -0.0681 & 0.0966 & -0.0305 & 0.132 & 0.226 \\
\hline head & $(0.139)$ & $(0.152)$ & $(0.134)$ & $(0.144)$ & $(0.150)$ \\
\hline Age of & 0.00227 & -0.000699 & -0.000566 & 0.00261 & -0.00273 \\
\hline household head & $(0.00342)$ & $(0.00333)$ & $(0.00313)$ & $(0.00329)$ & $(0.00354)$ \\
\hline Household size & $\begin{array}{l}-0.0422^{* *} \\
(0.0188)\end{array}$ & $\begin{array}{c}0.0506^{\star * *} \\
(0.0187)\end{array}$ & $\begin{array}{l}0.0336^{*} \\
(0.0174)\end{array}$ & $\begin{array}{l}0.0467^{* *} \\
(0.0183)\end{array}$ & $\begin{array}{l}0.00171 \\
(0.0200)\end{array}$ \\
\hline Education of & 0.0381 & -0.0342 & -0.00437 & 0.00522 & -0.0791 \\
\hline household head & $(0.0551)$ & $(0.0575)$ & $(0.0517)$ & $(0.0553)$ & $(0.0632)$ \\
\hline Household head & 0.0711 & -0.0319 & 0.0820 & -0.0697 & -0.0375 \\
\hline is married & $(0.138)$ & $(0.149)$ & $(0.132)$ & $(0.140)$ & $(0.146)$ \\
\hline \multicolumn{6}{|c|}{ alth status } \\
\hline Total household & $0.0690^{\star *}$ & 0.0391 & $0.0807^{* * *}$ & $0.0992^{* * *}$ & $0.0915^{\star * *}$ \\
\hline income (log) & $(0.0270)$ & $(0.0269)$ & $(0.0242)$ & $(0.0263)$ & $(0.0302)$ \\
\hline Asset index & $\begin{array}{c}0.000744 \\
(0.000647)\end{array}$ & $\begin{array}{c}0.00120^{*} \\
(0.000635)\end{array}$ & $\begin{array}{c}0.000830 \\
(0.000646)\end{array}$ & $\begin{array}{l}0.00104^{*} \\
(0.000585)\end{array}$ & $\begin{array}{l}-0.00207^{\star * *} \\
(0.000758)\end{array}$ \\
\hline Household includes & 0.0815 & 0.00802 & $0.195^{\star *}$ & 0.114 & $0.213^{\star *}$ \\
\hline someone with a savings account & $(0.0880)$ & $(0.0848)$ & $(0.0772)$ & $(0.0841)$ & $(0.0915)$ \\
\hline \multicolumn{6}{|c|}{ III. Household opportunity for diversified sources of income } \\
\hline $\begin{array}{c}\text { Household engaged in off-farm } \\
\text { employment }\end{array}$ & $\begin{array}{l}-0.266^{\star *} \\
(0.115)\end{array}$ & $\begin{array}{l}0.0660 \\
(0.105)\end{array}$ & $\begin{array}{l}0.0259 \\
(0.0969)\end{array}$ & $\begin{array}{l}-0.0122 \\
(0.104)\end{array}$ & $\begin{array}{c}0.141 \\
(0.106)\end{array}$ \\
\hline $\begin{array}{l}\text { Household in receipt } \\
\text { of remittance }\end{array}$ & $\begin{array}{l}-0.0719 \\
(0.0875)\end{array}$ & $\begin{array}{c}0.0582 \\
(0.0863)\end{array}$ & $\begin{array}{l}0.129^{*} \\
(0.0780)\end{array}$ & $\begin{array}{c}0.0649 \\
(0.0825)\end{array}$ & $\begin{array}{c}0.109 \\
(0.0903)\end{array}$ \\
\hline \multicolumn{6}{|c|}{ IV. Other variables } \\
\hline Distance to market & $\begin{array}{l}0.00306 \\
(0.0148)\end{array}$ & $\begin{array}{c}0.0226 \\
(0.0167)\end{array}$ & $\begin{array}{c}0.0226^{*} \\
(0.0131)\end{array}$ & $\begin{array}{l}0.0271^{* *} \\
(0.0126)\end{array}$ & $\begin{array}{l}-0.00302 \\
(0.0180)\end{array}$ \\
\hline Household has information on fertiliser & $0.323^{\star * *}$ & 0.101 & $0.152^{* *}$ & 0.0798 & 0.102 \\
\hline application & $(0.0821)$ & $(0.0801)$ & $(0.0737)$ & $(0.0784)$ & $(0.0864)$ \\
\hline $\begin{array}{l}\text { Household lives in } \\
\text { rural area }\end{array}$ & $\begin{array}{l}0.266^{\star * *} \\
(0.0966)\end{array}$ & $\begin{array}{l}0.719^{* * *} \\
(0.105)\end{array}$ & $\begin{array}{l}0.188^{* *} \\
(0.0859)\end{array}$ & $\begin{array}{c}0.118 \\
(0.0941)\end{array}$ & $\begin{array}{l}1.169 * * * \\
(0.119)\end{array}$ \\
\hline Pseudo $\mathrm{R}^{2}$ & 0.02 & 0.04 & 0.02 & 0.02 & 0.08 \\
\hline Wald $\mathrm{Chi}^{2}(13)$ & 40.99 & 99.67 & 50.02 & 48.73 & 139.35 \\
\hline Prob $>\mathrm{Chi}^{2}$ & 0.0001 & 0.0000 & 0.0000 & 0.0000 & 0.0000 \\
\hline Observations & 1,008 & 1,008 & 1,008 & 1,008 & 1,008 \\
\hline
\end{tabular}

Dependent variable: fertiliser use $=0$ if no fertiliser is used, $=1$ if inorganic fertiliser is used, $=2$ if both organic and inorganic fertiliser is used, $=3$ if organic fertiliser is used Robust standard errors in parentheses, ${ }^{* *} p<0.01,{ }^{* *} p<0.05,{ }^{*} p<0.1$

The ordered probit model estimation was run separately for each of the indigenous vegetables

Table 6: Maximum likelihood estimation results of the ordered probit model.

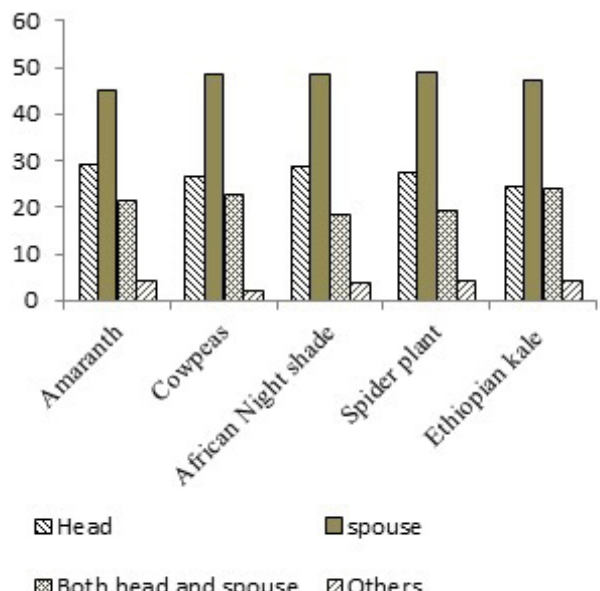

Household member responsible for AIV production

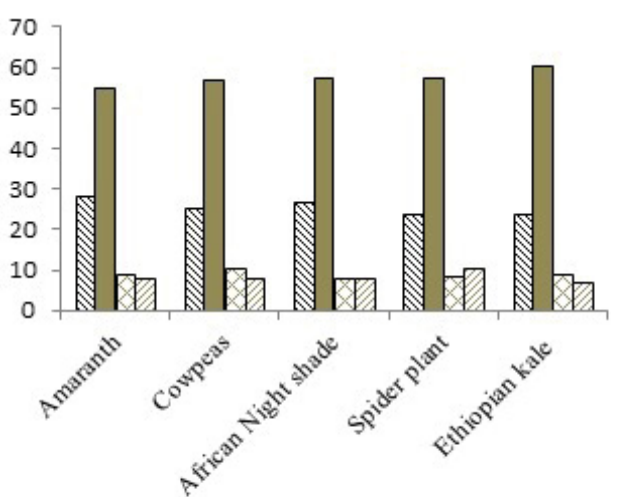

\&Head $\square$ spouse $\square$ Both head and spouse vOthers

Household member responsible for AIV marketing

Figure 1: Household members responsible for AIV production and marketing. 
Citation: Kebede SW, Bokelmann W (2017) African Indigenous Vegetables and their Production Practices: Evidence from the HORTINLEA Survey in Kenya. Agrotechnology 6: 170. doi: 10.4172/2168-9881.1000170

\section{Conclusion}

This paper reviewed the contribution of AIVs to household food security in general and their micronutrient contribution in particular. The contribution of AIVs to food security is undisputed since they provide a wide variety of nutrients and ease food insecurity tensions during periods of food shortages. Although undertaken on small areas of land, AIV production among the sampled producers was found to be close to a sustainable production approach. This is because most of the producers used organic fertilizers, which maximizes natural biological processes and promotes local biodiversity, both of which help improve soil fertility and environmental sustainability. Furthermore, the use of local seeds minimised the farm expenses and the cost of non-renewable inputs.

The paper identified the main socioeconomic factors determining the use of different types of fertilizer among AIV farmers. Different factors were found to influence the use of organic fertilizer for the different types of AIVs. Larger households in terms of household size were more likely to use organic fertilizer. Better-off households measured in different dimensions of welfare (namely income, assets and availability of saving accounts) have a higher tendency to use organic fertilizer. In addition, receipt of remittances, greater distance to market, access to information on fertilizer application and rural locations increased the likelihood of organic fertilizer being used in the production of AIVs.

Using household-level data and empirical analysis, this study supports the argument that AIV production follows sustainable agricultural production practices and uses organic farming practices $[9,10]$. Given the contribution of AIVs to food and nutrition security and the conformance of their production processes to sustainable production, it is recommended that their production and marketing be promoted and scaled up through active policy interventions.

\section{References}

1. Irungu C (2007) Analysis of Markets for African Leafy Vegetables within Nairob and its Environs and Implications for On-Farm Conservation of Biodiversity $1-45$.

2. Kimiywe J, Waudo J, Mbithe D, Maundu P (2007) Utilization and Medicinal Value of Indigenous Leafy Vegetables Consumed in Urban and Peri-Urban Nairobi 7: 1-16.
3. Schipmann C (2010) The food system transformation in developing countries: opportunities and challenges for smallholder farmers in Thailand. Uni Göttingen.

4. The World Bank (2006) Enhancing Agricultural Innovation: How to go beyond the strengthening of research systems. World 696.

5. McCullough EB, Pingali PL, Stamoulis KG (2010) Small Farms and the transformation of food systems: an overview. Haas R, Canavari M, Sle B, Tong C, Anurugsa B (Eds). Looking east looking west: organic and quality food marketing in Asia and Europe. Wageningen Academic Publishers.

6. International Fund for Agricultural Development (2010) New realities, new challenges : new opportunities for tomorrow's generation. Rome, Italy.

7. Weinberger K, Lumpkin TA (2007) Diversification into Horticulture and Poverty Reduction: A Research Agenda. World Dev 35: 1464-1480.

8. Woodhouse $\mathrm{P}$, Young T, Rigby D, Woodhouse $\mathrm{P}$, Young T, et al. (2001) Constructing a Farm Level Indicator of Sustainable Agricultural Practice Constructing a farm level indicator of sustainable 463-478.

9. Rubaihayo EB (2002) The contribution of indigenous vegetables to household food security. IK Notes 44: 1-4.

10. Okeno JA, Chebet DK, Mathenge PW (2003) Status of indigenous vegetable utilization in Kenya. Acta Horticulturae 621: 95-100.

11. Matson PA, Parton WJ, Power AG, Swift MJ (1997) Agricultural intensification and ecosystem properties. Science 277: 504-509.

12. Wooldridge JM (2002) Econometric Analysis of Cross Section and Panel Data. Booksgoogle.com 58: 752.

13. Schippers RR (2000) An Overview of the Cultivated Species An Overview of the Cultivated Species. London: Chatham, UK: Natural Resource Institute/ ACP-EU Technical Centre for Agricultural and Rural Cooperation.

14. Abukutsa M (2011) Keynote Paper : Strategic Repositioning of Agrobiodiversity in the Horticulture Sector for Sustainable Development in Africa 1-8.

15. Muhanji G, Roothaert RL, Webo C, Stanley M (2011) African indigenous vegetable enterprises and market access for small-scale farmers in East Africa. Int J Agri Sustain 9: 194-202.

16. Pretty J, Toulmin C, Williams S (2011) Sustainable intensification in African agriculture. Int J Agri Sustain 9: 5-24.

17. Tilman D, Cassman KG, Matson PA, Naylor R, Polasky S (2002) Agricultural sustainability and intensive production practices. Nature 418: 671-677.

18. Singh KP (2011) Agricultural Marketing and Rural Development. New Delhi: DPS Publishing House. 